\title{
In vivo footprint and methylation analysis by PCR-aided genomic sequencing: comparison of active and inactive $X$ chromosomal DNA at the CpG island and promoter of human PGK-1
}

\author{
Gerd P. Pfeifer, Robert L. Tanguay, Sabine D. Steigerwald, and Arthur D. Riggs \\ Beckman Research Institute of the City of Hope, Department of Biology, Duarte, California 91010 USA
}

The promoter region of the X-linked human phosphoglycerate kinase-1 (PGK-1) gene is a CpG island, similar to those often found near autosomal genes. We used ligation-mediated polymerase chain reaction (PCR) for a genomic sequencing study in which 450 bp of the human PGK-1 promoter region was analyzed for the presence of in vivo protein footprints and cytosine methylation at all $\mathrm{CpG}$ sites. A technique was devised to selectively visualize the DNA of the inactive $X$ chromosome (Xi), even in the presence of the active $X$ chromosome (Xa). We found that the human $\mathrm{Xa}$ in both normal male lymphocytes and hamster-human hybrids is completely unmethylated at all 120 CpG sites. In contrast, 118 of the CPG sites are methylated on the human Xi in hamster-human hybrids. The Xi in normal female lymphocytes is also highly methylated, but some GCG or CGC trinucleotides partially escape methylation; all other CpGs are fully methylated. In vivo footprinting studies with dimethylsulfate (DMS) revealed eight regions of apparent protein-DNA contacts on the Xa. Four of the footprints contained the consensus sequence of the binding site for transcription factor Sp1. The other regions include potential binding sites for transcription factors ATF, NF1, and a CCAAT-binding protein. The $\mathrm{Xi}$ did not show any specifically protected sequences, and with the exception of four hyperreactive sites, the in vivo DMS reactivity profile of Xi DNA was very similar to that of purified, linear Xi DNA. The implications of these findings with regard to the maintenance of methylation-free islands, $X$ chromosome inactivation, and the chromatin structure of facultative heterochromatin are discussed.

[Key Words: $\mathrm{X}$ chromosome inactivation, in vivo footprinting; DNA methylation; transcription factors]

Received April 4, 1990; revised version accepted May 22, 1990.

Information about cytosine methylation patterns and protein-DNA contacts is lost upon cloning but can be obtained by genomic sequencing (Church and Gilbert 1984; Saluz and Jost 1987). Genomic sequencing has recently been considerably improved by use of a ligationmediated polymerase chain reaction (LMPCR) to add specificity and to exponentially amplify sequence ladder fragments (Mueller and Wold 1989; Pfeifer et al. 1989). Here, we report the use of LMPCR-aided genomic sequencing for a study of the $\mathrm{CpG}$ island and promoter at the $5^{\prime}$ end of the human X-linked phosphoglycerate kinase-1 (PGK-1) gene. CpG-rich islands are found at the 5' ends of many genes, especially housekeeping genes (Bird 1986,1987 ), and studies using methylation-sensitive restriction endonucleases, such as HpaII, have shown that these islands are usually not methylated at the analyzable sites. It was the lack of methylation at HpaII sites that led to the discovery of $\mathrm{CpG}$ islands (Cooper et al. 1983). A long-standing question has been concerned with how these islands are maintained methylation free, because most (70-80\%) of HpaII sites are methylated in mammals.

In contrast to autosomal $\mathrm{CpG}$ islands, several on the inactive $\mathrm{X}$ chromosome were found to be highly methylated at HpaII sites (Wolf et al. 1984; Yen et al. 1984; Keith et al. 1986; Toniolo et al. 1988). X chromosome inactivation is a gene-silencing mechanism, unique to mammals, that affects almost all genes of a whole chromosome (for review, see Gartler and Riggs 1983; Grant and Chapman 1988). One of the two chromosomes in female cells becomes genetically silent in the early embryo at about the time of implantation. The inactive $\mathrm{X}$ chromosome $(\mathrm{Xi})$ is late-replicating and stays relatively condensed during interphase, whereas the active $\mathrm{X}$ chromosome $(\mathrm{Xa})$ is indistinguishable from autosomes. Thus, the $\mathrm{X}$ chromosome is facultatively heterochromatic, capable of being euchromatic in male cells and heterochromatic in female cells. The inactive state is somatically heritable and is an example of stable cell memory, which is a necessary part of normal mamma- 
lian development (Riggs 1989). There is rather convincing evidence that DNA methylation is important for the maintenance of $\mathrm{X}$ chromosome inactivation (for review, see Monk 1986; Grant and Chapman 1988; Lyon 1988; Riggs 1990). Some of the critical methylation sites involved in the maintenance of $\mathrm{X}$ chromosome inactivation may be found in $\mathrm{CpG}$ islands, because sex-specific island methylation is correlated with stability of the inactive state (Kaslow and Migeon 1987; Migeon et al. 1989).

In general, numerous studies have established that there is a good correlation between methylation of regulatory regions and transcriptional silence (for review, see Razin and Riggs 1980; Doerfler 1983; Riggs and Jones 1983; Cedar 1988; Grünwald and Pfeifer 1989), but the mechanisms involved in the suppression of gene expression by DNA methylation are largely unknown. Interference by cytosine methylation with the binding of transcription factors is one possibility, as the binding of some transcription factors is eliminated or reduced by CpG methylation (Becker et al. 1987; Kovesdi et al. 1987; Watt and Molloy 1988; Hermann et al. 1989; Iguchi-Ariga and Schaffner 1989). However, SP1 and CTF bind to their recognition sites irrespective of methylation (Harrington et al. 1988; Höller et al. 1988; BenHattar et al. 1989). Suppression of transcription and/or the formation of inactive chromatin (Cedar 1988) by methylation could be brought about also by binding of a protein(s) that interacts with methylated DNA, independent of sequence. One such protein identified in human placenta shows a limited sequence specificity (Huang et al. 1984; Wang et al. 1986). Another protein recently identified by Bird and co-workers has no obvious sequence specificity but requires clusters of methylated CpGs (Meehan et al. 1989). Such a protein would be a candidate for binding to methylated $\mathrm{CpG}$ islands on the $\mathrm{Xi}$. However, prior to this study there was no direct evidence that proteins can bind differentially to DNA regions on the $\mathrm{Xa}$ and the Xi. Here, we report on the presence of specific in vivo protein-DNA contacts within a $\mathrm{CpG}$ island on $\mathrm{Xa}$ and $\mathrm{Xi}$. In addition, the complete strand-specific DNA methylation pattern of a CpG island has been determined.

\section{Results}

\section{Methylation analysis and selective visualization of the} $\mathrm{Xi}$ in female cells

Chemical DNA sequencing distinguishes methylated from unmethylated cytosines because, at high salt concentrations, the base-modifying agent hydrazine does not react with 5-methylcytosine; thus, a gap appears in the $\mathrm{C}$ lane of a sequence ladder (Church and Gilbert 1984). The LMPCR procedure used here is outlined in Figure 1A. This procedure preserves methylation information because the chemical sequencing reactions are done before the PCR amplification (Mueller and Wold 1989; Pfeifer et al. 1989|. Briefly, the first step is basespecific chemical cleavage of DNA at either G, G + A,
A

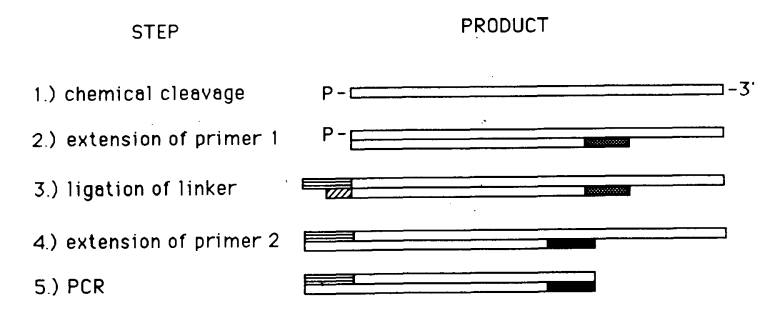

B

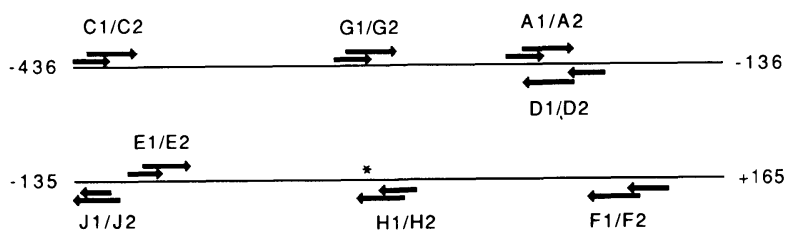

Figure 1. $(A)$ Outline of the LMPCR procedure. The open bars represent single DNA strands. Oligonucleotide primers are shown as shaded or black boxes. $|B|$ Position of the oligonucleotide primers used for LMPCR in the $5^{\prime}$ region of human PGK-1. The asterisk $\left({ }^{*}\right)$ marks the major transcription initiation site.

$\mathrm{T}+\mathrm{C}$, or $\mathrm{C}$, generating $5^{\prime}$-phosphorylated molecules. Next, primer extension of a gene-specific oligonucleotide (primer 1) generates molecules that have a blunt end on one side. Linkers are ligated to the blunt ends, and an exponential PCR amplification of the linker-ligated fragments is done by using the longer oligonucleotide of the linker (linker-primer) and a second gene-specific primer (primer 2). After performing 15-18 amplification cycles, the DNA fragments are separated on a sequencing gel, electroblotted onto nylon membranes, and hybridized with a gene-specific probe to visualize the sequence ladder. By rehybridization, several gene-specific ladders can be sequentially visualized from one sequencing gel (Pfeifer et al. 1989).

To analyze both strands of a 450-bp region at the $5^{\prime}$ end of the human PGK-1 gene, we have used eight different oligonucleotide primer sets (Fig. 1B), often using two sets simultaneously. Representative sequencing data are shown in Figure 2. The relative band intensities are very reproducible if adequate amounts of DNA are used. For this region and primer sets, $\sim 1 \mu \mathrm{g} / \mathrm{lane}$ is sufficient (for a discussion of statistical factors; see Pfeifer et al. 1989). Sites of potential methylation (CpG) are indicated in Figure 2. In lanes 5 and 9 (Fig. 2), which show DNA from an $\mathrm{Xi}$, methylation is indicated at several sites by the band intensity dropping to the background level. Methylated sites are not seen in other lanes, including lane 11 (Fig. 2), which shows cloned DNA. For bands appearing weak in the exposure shown, longer exposures were used; methylation information was obtained at every $\mathrm{C}$.

Direct analysis of DNA from female human diploid cells does not give easily interpretable results, because both $\mathrm{Xa}$ and $\mathrm{Xi}$ are present. To selectively reveal $\mathrm{Xi}$ DNA in female cells, we took advantage of the known 


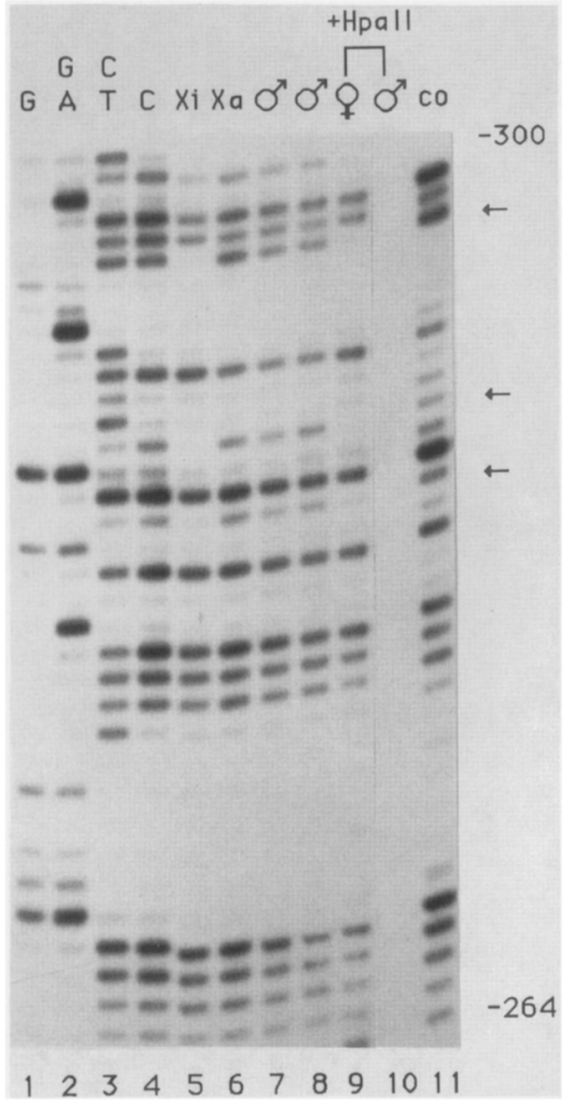

Figure 2. Methylation analysis with primer set D. Arrows indicate the position of CpG dinucleotides. Lanes 1-3 are sequencing controls $(G, G+A, T+C)$ from HeLa cells. Lanes 4-11 are C-specific reactions: (Lane 4) HeLa cells; (lane 5) hybrid cells containing human $\mathrm{Xi}_{\text {; }}$ (lane 6 ) hybrid cells containing human $\mathrm{Xa}$; (lanes 7 and 8) male lymphocytes; (lane 9) female lymphocytes after HpaII cleavage to remove Xa DNA; (lane 10) male lymphocytes after HpaII cleavage; (lane 11) cloned DNA.

differential methylation state of the HpaII sites in this region on the $\mathrm{Xa}$ and $\mathrm{Xi}$ in female blood cells (Keith et al. 1986). For example, using a quantitative methylation assay, Steigerwald et al. (1990) found that the HpaII site at position +23 in this region is $>98 \%$ unmethylated on the $\mathrm{Xa}$ in normal male lymphocytes and $50 \%$ methylated in the $\mathrm{Xa} / \mathrm{Xi}$ mixture in normal female lymphocytes. The strategy outlined in Figure 3 simplifies the sequence ladders and may be generally applicable for allele- or imprint-specific methylation differences. Cleavage of DNA with $H$ paII cuts the $5^{\prime}$ region from the $\mathrm{Xa}$ to small fragments. The LMPCR primers were selected so as to be close to HpaII sites or to contain a HpaII site within the primer sequence. Two of the primer sets could not be arranged to be near HpaII sites. In this case, the proximity of other methylation-sensitive restriction enzyme sites (HhaI for primer set J and FspI for primer set C) was exploited. After cutting female DNA with the respective methylation-sensitive restriction enzyme, the first primer extension reaction proceeds only to the site of the restriction cut in DNA de- rived from the Xa. DNA from the Xi remains uncut, and the primer extension and amplification reactions proceed over the whole sequence $3^{\prime}$ to the cut (Fig. 3). Male lymphocyte DNA is completely removed from the sequencing gel by prior cutting with $\mathrm{HpaII}$ (Fig. 2, lane 10; Fig. 4, lane 10). However, the sequence ladder is retained above the HpaII cut in female (e.g., Fig. 2, lane 9; Fig. 4, lanes 8 and 9). The only likely interpretation is that the ladder above the HpaII site comes from Xi.

\section{Methylation differences between Xa and Xi}

Active X chromosomal DNA was studied in HeLa cells, male human lymphocytes, and Chinese hamsterhuman hybrid cells containing a human Xa /cell line Y162-11C). Figures 2 and 4 show results obtained with primer sets $\mathrm{D}$ and $\mathrm{H}$. By determining relative band intensities between adjacent bands in the same sequence ladder and then comparing with cloned, unmethylated DNA, it can be seen that DNA from male lymphocytes is not detectably methylated at any of the CpG dinucleotides (Fig. 2, lanes 7 and 8; Fig. 4, lanes 6 and 7), and the same is true for DNA from hybrid cells containing human Xa (Fig. 2, lane 6; Fig. 4, lane 5). HeLa cell DNA also is unmethylated in this region (Figs. 2 and 4), consistent with this cell line having only Xa. Methylation data for the whole region are summarized in Figure 5. DNA from the $\mathrm{Xa}$ is not detectably methylated at any of the $120 \mathrm{CpG}$ dinucleotides in the analyzed region.

In contrast, human Xi in Chinese hamster-human hybrid cells (X86T2) has a very high level of methylation (Fig. 5C). Only one $\mathrm{CpG}$ is not detectably methylated
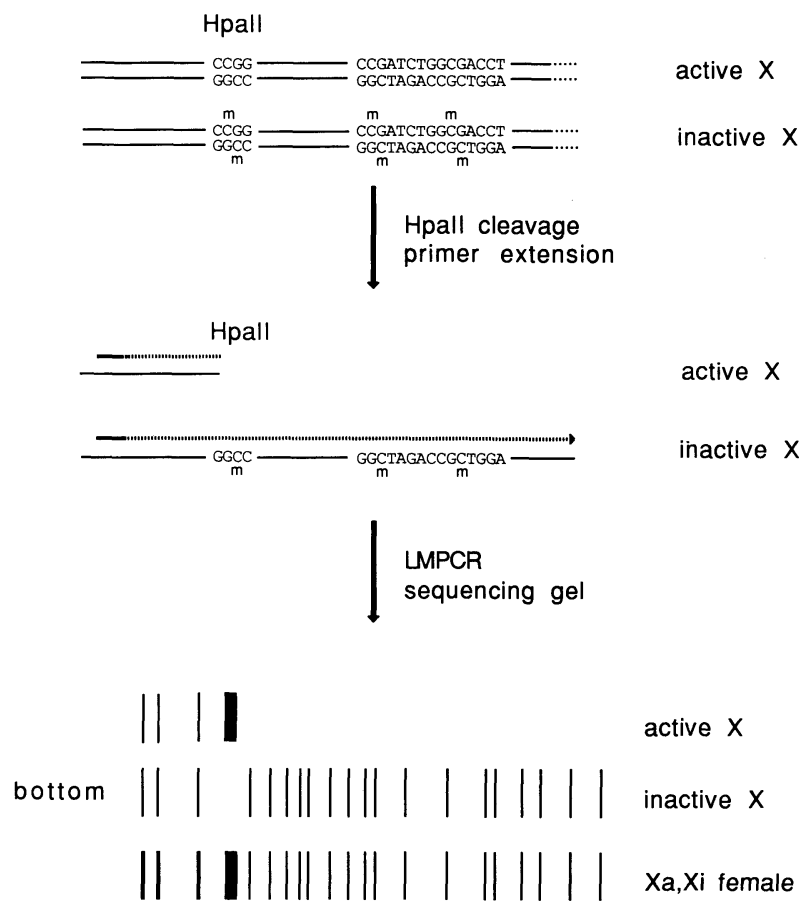

Figure 3. Outline of the method used to separate Xa DNA from $\mathrm{Xi}$ for genomic sequencing and in vivo footprinting. 


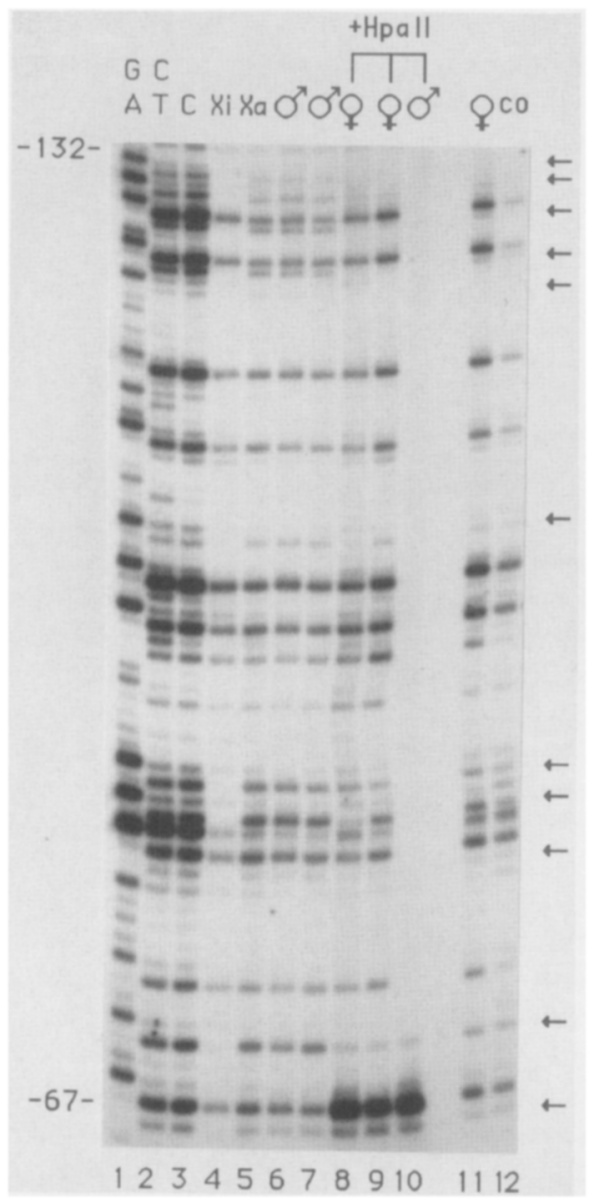

Figure 4. DNA methylation analysis with primer set $\mathrm{H}$. Arrows indicate the position of CpG dinucleotides. Xa DNA was removed from female DNA by Hpall digestion at position -67. Cloned DNA was used as an unmethylated control. (Lanes 1 and 2) Sequencing controls $(G, G+A$ ) obtained from HeLa DNA; (lanes 3-12) C-specific reactions. Some bands seen at $G$ positions in the $C$ lanes are side reactions of hydrazine with G. They do not affect methylcytosine analysis. (Lane 3) HeLa cells; (lane 4) hybrid cells containing a human $\mathrm{Xi}$; (lane 5 ) hybrid cells containing a human Xa; (lanes 6 and 7) male lymphocytes; (lanes 8 and 9) female lymphocytes after HpaII cleavage; (lane 10) male lymphocytes after HpaII cleavage; (lane 11) female lymphocytes without HpaII cleavage; (lane 12) cloned DNA.

(position -260). This same site is also not methylated on the $\mathrm{Xi}$ in female lymphocytes (Fig. 5B). One site (position -257) in the human-hamster hybrid cells is partially methylated; however, all other sites (a total of 116) are not detectably unmethylated, that is, the band seen is not greater than the background level for that position. Xi DNA from female lymphocytes shows mostly fully methylated sites (Fig. 5B); but, some sites appear to be only partially ( 40 to $80 \%$ ) methylated (Figs. 2, 4, and 5). This partial methylation cannot be explained by incomplete digestion and thus, incomplete removal of the Xa ladder, because fully methylated sites are found in the same lane of the sequencing gel. Therefore, we conclude that the $\mathrm{Xi}$ in female lymphocytes contains some sites that are only partially methylated. This is also consistent with results obtained by Southern blotting that indicated partial demethylation of some $H$ haI sites and a NarI site (D. Keith, unpubl., and data not shown). The majority $(75 \%)$ of CpG sites on lymphocyte Xi are fully methylated. The $25 \%$ of the CpG sites in female lymphocytes that are only partially methylated on the $\mathrm{Xi}$ (Fig. 5B) are all located in the trinucleotide GCG or its complement CGC. However, not all of these trinucleotides escape full methylation, so there seem to be some additional sequence requirements. For example, many of the partially methylated GCGs are in a very high G + C sequence context. In most cases, a sequence of five or more adjacent $\mathrm{G} / \mathrm{C}$ base pairs with a central CGC or GCG trinucleotide does not become completely methylated.

\section{In vivo footprinting of $\mathrm{X} a$ and $\mathrm{Xi}$}

By using the same combination of primers, we have in-

A

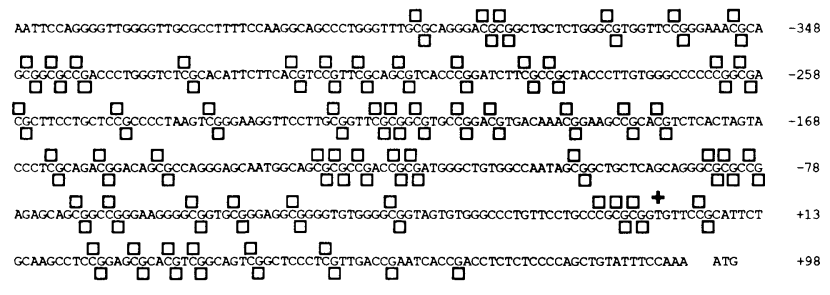

B

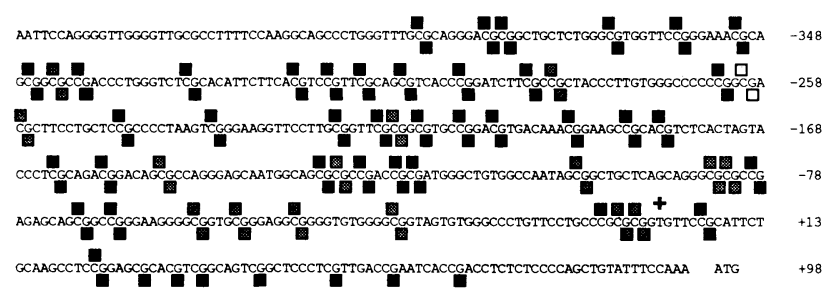

C

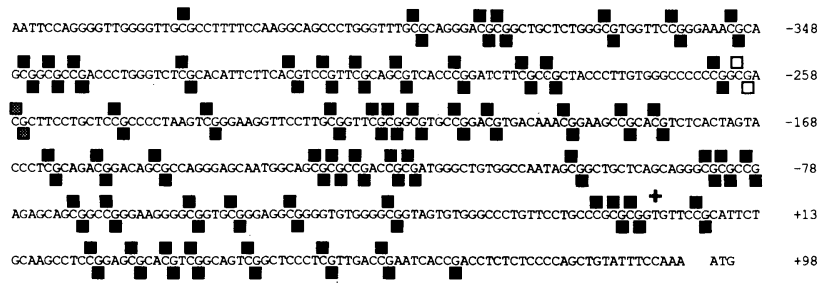

Figure 5. Summary of DNA cytosine methylation in the CpG island of X-linked PGK-1. (ㅁ) Unmethylated sites; ( $\square$ ) fully methylated sites; (shaded squares) partial methylation $(40-80 \%)$ at these positions. (+) The major transcription initiation site; the ATG at +96 is the translation initiation codon. The methylation of one site on the lower strand at position -7 is not known, because a strong signal appeared across all lanes of the sequencing gel (even in the G, and $G+A$ channels). This is probably due to a premature termination of Taq polymerase within this region, but it could also be caused by a specific nick. (A) DNA from Xa. DNAs studied were from male lymphocytes, HeLa cells, and Y162-11C hybrid cells containing human Xa. $(B)$ DNA from the Xi of female lymphocytes. $(C)$ DNA from the human Xi in X86T2 hybrid cells. 
vestigated in vivo protein-DNA interactions by dimethylsulfate (DMS) footprinting. DMS reacts with the N7 position of guanosines, enabling later cleavage by piperidine. The ability of DMS to penetrate cell membranes has allowed its use for true in vivo footprinting experiments (Ephrussi et al. 1985). Proteins in contact with DNA either decrease accessibility of specific guanosines to DMS (protection) or, often at the edges of a footprint, increase reactivity (hyperreactivity).

In vivo footprints on active $\mathrm{X}$ chromosome DNA was studied in HeLa cells, male human lymphocytes, and hamster-human hybrid cells (Y162-11C) containing the human $\mathrm{Xa}$. The Xi was analyzed first for protein footprints in hybrid cells containing a human Xi (X86T2) and then in normal female lymphocytes by selective removal of Xa DNA, as was done for methylation analysis. Figure 6 shows differential in vivo footprints on the $\mathrm{Xa}$ and $\mathrm{Xi}$. There is a region of strong protein-DNA interaction at nucleotide position -40 to -65 relative to the major transcription initiation site. This region (footprints I and II, see Fig. 9, below) contains two Sp1 consensus sequences (Briggs et al. 1986). These sequences are protected in vivo and are separated by a hyperreactive guanosine on the upper strand (Figs. 6 and 7) and a

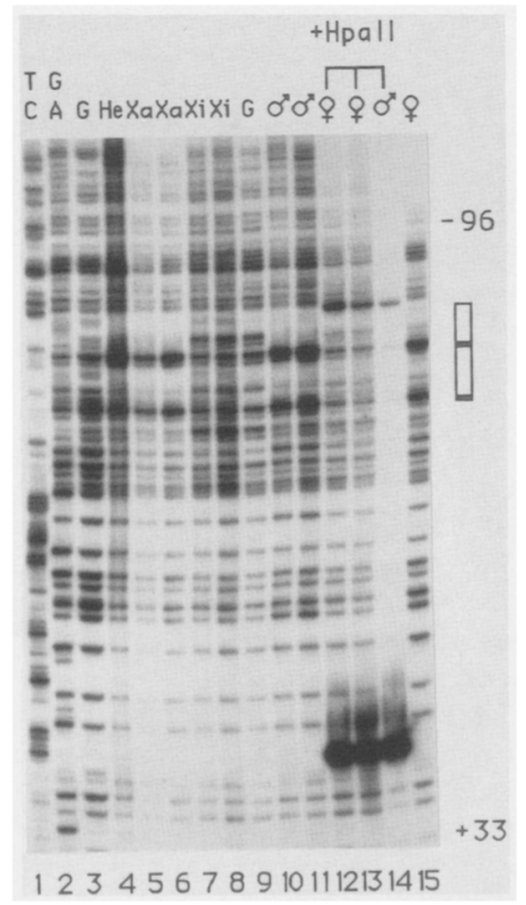

Figure 6. In vivo DMS footprinting of $\mathrm{Xa}$ and $\mathrm{Xi}$ DNA with primer set $\mathrm{F}$. Footprints on the $\mathrm{Xa}$ are indicated by a box; they correspond to footprints I and II (see Fig. 9). Lanes 1 and 2 are sequencing controls $(\mathrm{T}+\mathrm{C}, \mathrm{G}+\mathrm{A})$. Naked DNA controls are in lanes 3 (HeLa DNA) and 9 (X86T2 cells). In vivo DMS-treated samples were obtained from HeLa cells (lane 4), hybrids containing a human $\mathrm{Xa}$ (lanes 5 and 6), hybrids containing a human $\mathrm{Xi}$ (lanes 7 and 8), male lymphocytes (lanes 10 and 11), female lymphocytes after HpaII cleavage (lanes 12 and 13), male lymphocytes after HpaIII cleavage (lane 14), and female lymphocytes without HpaII cleavage (lane 15).

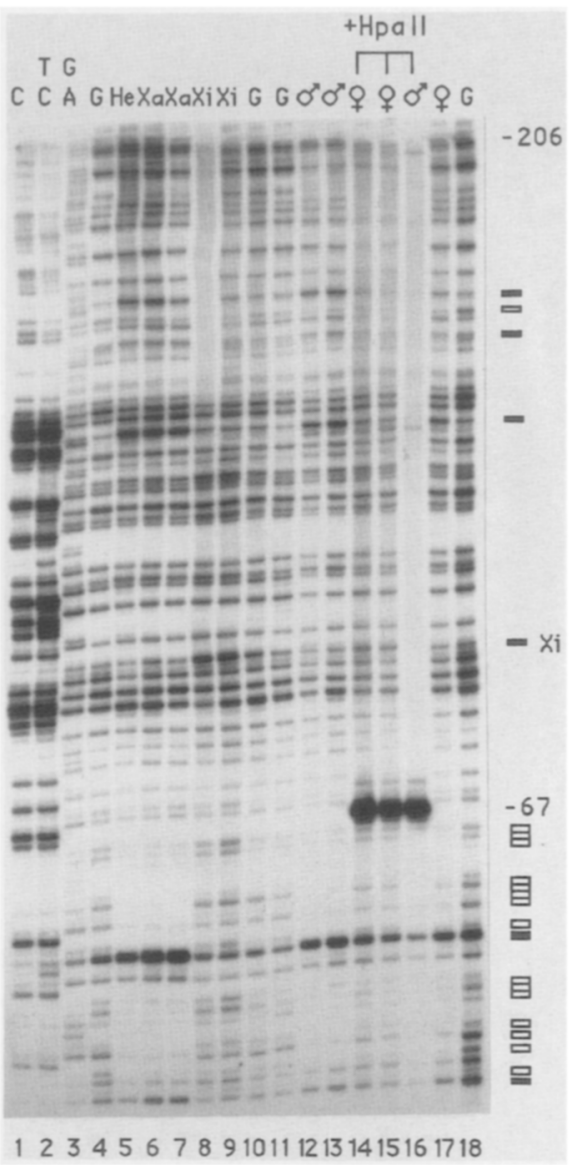

Figure 7. In vivo DMS footprinting of $\mathrm{Xa}$ and $\mathrm{Xi}$ DNA with primer set $\mathrm{H}$. Hyperreactive sites are indicated by solid boxes; protected guanosines are shown by open boxes. Xi marks a hyperreactive site on the $\mathrm{Xi}$. The lower part of the gel contains footprints I and II (see Fig. 9) in higher resolution. The upper part indicates the reactivity differences characteristic for footprint IV. Lanes 1-3 are sequencing controls $(C, T+C, G+A)$. Naked DNA controls are in lanes 4, 18 (HeLa DNA), 10 (X86T2), and 11 (Y162-11C cells). (Lane 5) In vivo DMS-treated samples were obtained from HeLa cells; (lanes 6 and 7) hybrids containing human $\mathrm{Xa}$; (lanes 8 and 9) hybrids containing human Xi; (lanes 12 and 13) male lymphocytes; (lanes 14 and 15) female lymphocytes after HpaII cleavage; (lane 16) male lymphocytes after HpaII cleavage; and (lane 17) female lymphocytes without HpaII cleavage.

hyperreactive adenosine on the lower strand (not shown). Therefore, we assume that two proteins (possibly Sp1) are binding to this region. These in vivo footprints are observed only on the $\mathrm{Xa}$, and they are identical between HeLa cells, male human lymphocytes, and hamster-human hybrid cells containing a human $\mathrm{Xa}$. There is no in vivo protein-DNA contact in this region on the $\mathrm{Xi}$ in hybrid cells containing a human $\mathrm{Xi}$ and on the $\mathrm{Xi}$ in female lymphocytes. Figure 6, lanes 12 and 13, shows data from an experiment in which Xa DNA was removed from the sequence ladder by prior HpaII digestion at position +23 . The band just above the footprints (position -67; Fig. 6) is a HpaII site and thus probably is due to $<100 \%$ complete restriction digestion. It does not 
affect the interpretation of the footprints because Xaspecific footprints disappear in female DNA after HpaII treatment. Without removal of the Xa from female DNA by HpaII cutting, an intermediate footprint reflecting a mixture of the $\mathrm{Xa}$ and $\mathrm{Xi}$ was obtained (Fig. 6, lane 15). These results show that transcription factors bind to this region selectively on an $\mathrm{Xa}$ in female cells, as they do in cells containing Xa only. A more detailed resolution of the -40 to -65 footprint is shown in Figure 7, in which we used primer set $\mathrm{H}$. Xa and Xi DNA are not separated in this region $(-40$ to -65$)$ in DNA from female cells, because the HpaII site is located farther downstream. There is an additional region of proteinDNA interaction near nucleotide position -140 to - 155 on $\mathrm{Xa}$, which possibly extends to a region near -115 (footprint IV, see Fig. 9). Figure 8 shows another footprint on DNA from the Xa between nucleotides -240 and -258 (footprint VI, see Fig. 9). This region contains another $\mathrm{Spl}$ consensus sequence.

The DMS reactivity profiles of Xi DNA in normal female lymphocytes and X86T2 cells look very similar to the purified DNA that is used as a control (e.g., Fig. 6, lane 9; Fig. 7, lane 10). It should be noted that the DMS reactivity of naked DNA is slightly different between highly methylated and unmethylated DNA (cf. DNA from X86T2 and Y162-11C; Fig. 8, lanes 6 and 7). There-

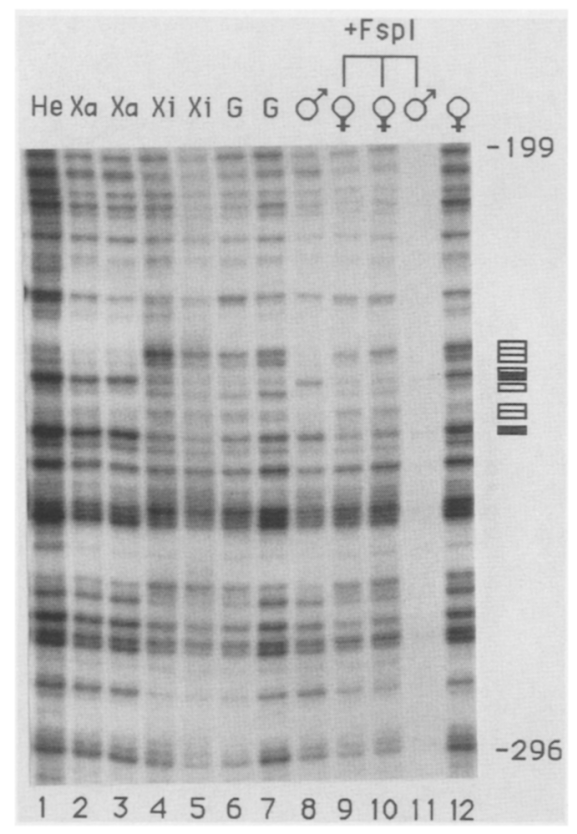

Figure 8. In vivo DMS footprinting of $\mathrm{Xa}$ and $\mathrm{Xi}$ DNA with primer set C. ( $\square$ ) Hyperreactive sites; $(\square)$ protected guanosines. The gel shows the lower-strand interactions at the -240 region (footprint VI, Fig. 9). Naked DNA controls are in lanes 6 (X86T2 cells) and 7 (Y162-11C cells). (Lane 1) In vivo DMS-treated samples were obtained from HeLa cells; (lanes 2 and 3) hybrids containing human $\mathrm{Xa}$; (lanes 4 and 5) hybrids containing

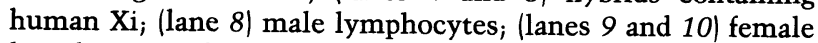
lymphocytes after FspI cleavage; (lane 11) male lymphocytes after FspI cleavage; and (lane 12) female lymphocytes without FspI cleavage. fore, both controls of naked DNA were always included. No specific protection of guanosines were seen on the $\mathrm{Xi}$ in the whole region investigated. However, there are some guanosines that are hyperreactive with DMS on the Xi in vivo (Figs. 7 and 10, below). This hyperreactivity is not accompanied by a specific protection in the neighborhood, as seen for Xa footprints. In two of four cases, two immediately adjacent guanosines in the sequence $\mathrm{GpG}$ were found to be hyperreactive (Fig. 9).

A summary of the in vivo footprinting data is shown in Figure 9. One of the footprints located around nucleotide position -360 (footprint VIII, Fig. 9) on the Xa is seen only in HeLa cells (data not shown). It corresponds to a region that is specifically protected in vitro by a HeLa cell extract (Yang et al. 1988). Another protected region (footprint $\mathrm{V}$ ) is detected only in lymphocytes but not in HeLa or hybrid cells (Fig. 10). Again, this footprint is seen only on the $\mathrm{Xa}$.

Information on overall DMS reactivity of the Xi relative to $\mathrm{Xa}$ is also contained in our data. A small reduction in reactivity of Xi DNA is seen, and this may be significant because in female lymphocytes, the ratio of band intensities in the ladder above and below the relevant HpaII site can be measured. Thus, there is an internal control. Comparative densitometry of the data in Figure 6 (lanes 12 and 15) indicates that the band intensities above the HpaII site are $30 \%$ more reduced than the expected $50 \%$. It can be concluded that DMS reactivity is not dramatically different between $\mathrm{Xa}$ and $\mathrm{Xi}$ islands, as might have been the case if the $\mathrm{Xi}$ were covered by a sequence-nonspecific, but tight, binding protein.

\section{Discussion}

Methylation of $C p G$ islands

Our results extend the presently available data on DNA methylation in $\mathrm{CpG}$ islands to all $\mathrm{CpG}$ dinucleotides in the PGK-1 promoter region. Not only are restriction sites unmethylated on Xa, but so is each of a total of 120 analyzed CpG dinucleotides. In dramatic contrast, the same region on the $\mathrm{Xi}$ is very highly methylated. Despite reports suggesting some methylation at sites other than CpG in mammals (Crowther et al. 1989), we have not observed any methylation in dinucleotides other than CpG. Furthermore, we have not seen hemimethylated sites, the occurrence of which may be limited to certain critical gene regions in the course of gene activation (Saluz et al. 1986). A human Xi in a Chinese hamster background retains a high level of methylation, indicating that the methylation system is most likely highly conserved. Surprisingly, one CpG dinucleotide at position -260 escapes methylation completely in the hybrids and in normal female lymphocytes. There is no protein footprint on the $\mathrm{Xi}$ in this region. The only obvious sequence peculiarity is a stretch of six Cs in close proximity to the unmethylated site. Methylation of some sites on the $\mathrm{Xi}$ in female lymphocytes is partial, suggesting either less efficient maintenance than in hybrid cells or a mixture of cell types with specific methyl- 


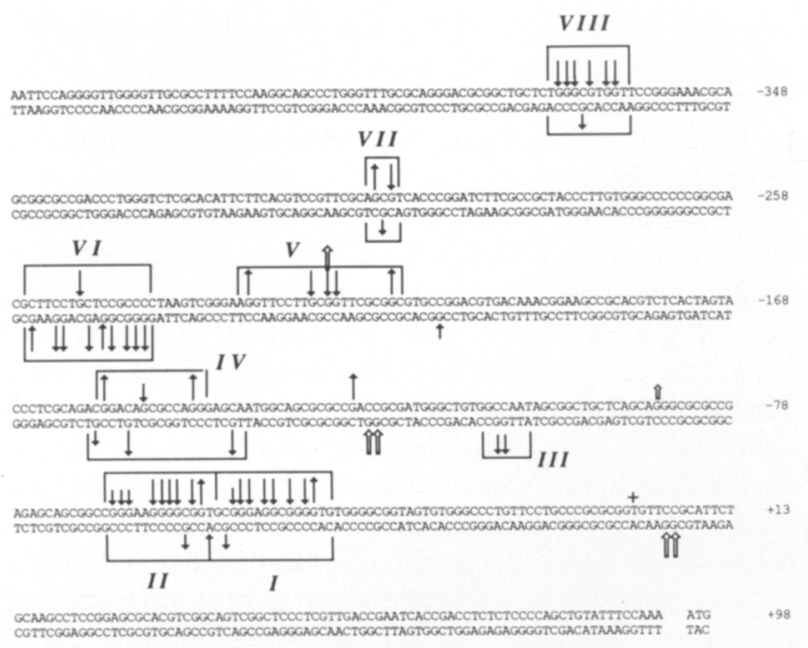

Figure 9. Summary of in vivo footprinting data. Protection of specific guanosines on the upper or lower strand is indicated by downward arrows. Hyper-reactive sites are marked by upward arrows. Hyperreactive sites on $\mathrm{Xi}$ are shown by upward open arrows. Roman numerals name the individual footprints (see text). $(+\mid$ The major transcription initiation site.

ation patterns. It has been shown recently that a partial methylation profile at a specific site can be stably maintained in tissues and cell lines (Turker et al. 1989). The partial methylation that we see is not correlated with protein footprints and is seen only at some GCG or CGC trinucleotides; thus, there may be a bias of DNA methyltransferase against certain DNA sequences. Mammalian DNA methyltransferase does show a preference for certain CpGs in vitro (Bolden et al. 1986; Smith et al. 1989). The undermethylated GCG trinucleotides that we find are surrounded by several G/C base pairs and, thus, are very $\mathrm{G}+\mathrm{C}$-rich sites. It has been proposed that DNA methyltransferase acts by "opening" the DNA helix (Adams and Burdon 1985), consistent with a bias against G/C-rich target sequences /Carotti et al. 1989|.

\section{Factors bind selectively to $\mathrm{Xa}$}

We have identified in vivo eight different footprints in the $\mathrm{CpG}$ island of PGK-1 on Xa, suggesting binding of sequence-specific proteins. No footprints are seen on $\mathrm{Xi}$ in hybrids and female cells. This result emphasizes that the mere presence of a transcription factor in the cell does not necessarily mean that it actually binds to its recognition sequence in vivo (see also Becker et al. 1987; Mueller and Wold 1989). By sequence analysis, the investigated region has five potential binding sites for transcription factor Sp1. Three of these sites show a footprint in all cell types that contain an Xa (footprints I, II, and VI; Fig. 9). One footprint at -360 (footprint VIII) is seen only in HeLa cells, and one $\mathrm{Spl}$ consensus sequence at -30 is not protected at all in any cell type, indicating that potential Spl-binding sites can be selectively occupied in vivo. Earlier work using in vitro foot- printing and HeLa cell extracts (Yang et al. 1988) revealed, for the $\mathrm{Sp} 1$ consensus sequences, only the -360 footprint. Another protected region observed in the in vitro study and centered at position -130 is also seen in vivo (footprints III and IV); however, the most prominent reactivity differences are seen at the left-most boundary $(-140$ to -155$)$. The region of footprint IV shows a significant homology to a high-affinity NF1binding site (Nilsson et al. 1989). Two guanosines of the CCAAT element at position -108 are also protected (footprint III). The PGK-1 promoter contains no TATA box, and the region near the transcription initiation sites shows no obvious sequence-specific protein-DNA interactions detectable by in vivo DMS footprinting. Because a consensus sequence for HIP1 (Means and Farnham 1990) is at the transcription start point of PGK-1, it should be noted that our in vivo DMS studies have not revealed a footprint for HIPl. This new factor has been proposed to be a general factor for $G+C$-rich promoters and to bind near the transcription start point (Means and Farnham 1990). Footprint VII, which spans only a few nucleotides, contains a consensus sequence (CGTCA) for the transcription factor ATF (Lee et al. 1989|. Footprint V, which is seen only in lymphocytes, shows no obvious sequence similarity to any known binding sequences of transcription regulatory proteins.

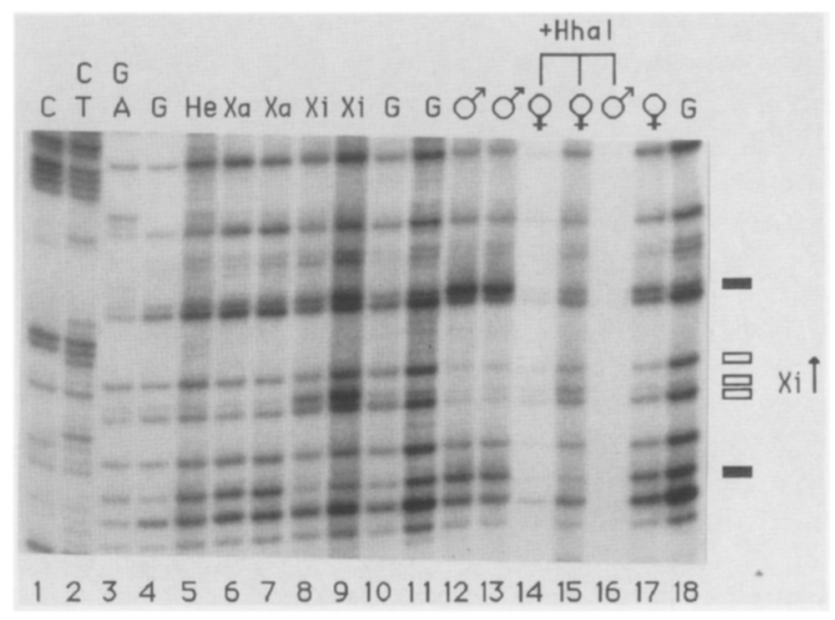

Figure 10. In vivo DMS footprinting of $\mathrm{Xa}$ and $\mathrm{Xi}$ DNA analyzed with primer set $\mathrm{J}$. This region contains a lymphocyte-specific in vivo footprint (footprint V, Fig. 9; nucleotide position -210 to -230 ). Because there is partial methylation at some HhaI sites (see Fig. 5), primer set J analyzes only those molecules from Xi in female DNA that are completely methylated at the relevant sites. Hyperreactive sites are indicated by solid rectangles; protected guanosines are shown by open rectangles. A hyperreactive site on $\mathrm{Xi}$ is also seen. Lanes 1-3 are sequencing controls $(\mathrm{C}, \mathrm{T}+\mathrm{C}, \mathrm{G}+\mathrm{A})$. Naked DNA controls are in lanes 4, 18 (HeLa cell DNA), 10 (X86T2 cells), and 11 (Y162$11 \mathrm{C}$ cells). (Lane 5 ) In vivo DMS-treated samples were obtained from HeLa cells; (lanes 6 and 7) hybrids containing human $\mathrm{Xa}$;

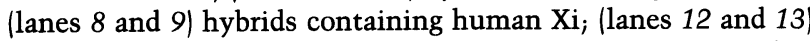
male lymphyocytes; (lanes 14 and 15) female lymphocytes after HhaI cleavage; (lane 16) male lymphocytes after HhaI cleavage; and (lane 17) female lymphocytes without $\mathrm{HhaI}$ cleavage. 
Six of the eight sequences of human PGK-1 identified by the presence of in vivo footprints (I, II, III, IV, VI, and VII) show a high degree of homology to mouse sequences that are similarly spaced in the promoter of mouse PGK-1 (Adra et al. 1987). Also of significance is that the same in vivo footprint patterns are seen in human cells and in hamster-human hybrid cells, suggesting again, as for methylation, a high degree of evolutionary conservation.

\section{Heterochromatin structure and the $\mathrm{Xi}$}

The Xi has the cytological features and genetic silence typical of heterochromatin, yet the $\mathrm{Xi}$ is of particular interest because in female cells a chromosome with indistinguishable base sequence (inbred mice) is maintained euchromatic. What is the difference between euchromatin and facultative heterochromatin? The LMPCR procedure, in conjunction with HpaII treatment, has allowed us to compare facultative heterochromatin and euchromatin in vivo for the first time. We find that the DMS reactivity profile of the $\mathrm{Xi}$ is very similar to torsion-free, protein-free DNA. The DMS reaction profile of the PGK-1 promoter region in supercoiled plasmid DNA is distinguishably different (G.P. Pfeifer et al., unpubl.), and the eight protein footprints apparent on the $\mathrm{Xa}$ are definitely not seen on the $\mathrm{Xi}$. At first contemplation, these results seem to be at odds with the cytologically condensed state of the Xi. One might have expected that the heterochromatic Xi would have, as do some satellite DNAs (Levinger and Varshavsky 1982) and Drosophila heterochromatin (James and Elgin 1986; Reuter et al. 1990|, a unique DNA-binding factor or set of bound factors that would give an Xi-specific footprint pattern. However, heterochromatin has been reported to have less nonhistone proteins than euchromatin (Comings et al. 1977). Moreover, with an important exception that will be discussed below, several nuclease digestion studies on isolated nuclei have indicated that general nuclease accessibility of the $\mathrm{Xi}$ is not much different from that of the $\mathrm{Xa}$ and bulk chromatin (Lin and Chinault 1988; Antequera et al. 1989). If nuclease accessibility is a reflection of higher order chromatin structure, these results suggest only small global differences in structure between euchromatin and facultative heterochromatin.

Our studies do not yet provide much direct information about nucleosome structure and phasing, because it is known that the DMS reactivity profile of DNA in nucleosomes is not very different from free DNA; the N7 of guanine is as solvent and (DMS) accessible in nucleosome DNA as in DNA free of protein (McGhee and Felsenfeld 1979; Wang and Becker 1988). The only difference reported is an enhanced reactivity at approximately nucleotide 62 from the $5^{\prime}$ end of the nucleosome (McGhee and Felsenfeld 1979). The only feature of Xi DNA that we observe to be significantly different from protein-free DNA is enhanced DMS reactivity of Gs at positions $+4,5,-87,-122,123$, and -218 . These sites of enhanced reactivity could possibly be a reflection of phased nucleosomes, but the spacing between the sites is not obviously consistent with this notion. Hyperreactive sites could also be caused by altered DNA conformation in vivo (Z-DNA, bent DNA, etc.), which could be influenced directly or indirectly by the high level of methylation.

We cannot rule out that methylation alone is sufficient in vivo for maintenance of the inactive state. The simplest explanation would be that transcription factors do not bind to DNA that is completely methylated. However, Spl binding was shown to be not methylation sensitive or only weakly methylation sensitive in vitro (Harrington et al. 1988; Höller et al. 1988; Ben-Hattar et al. 1989). Meehan et al. (1989) have identified a protein (MeCP) that binds preferentially to clusters of 15 or more methylated CpGs. MeCP binding at methylated CCGG sites inhibits the action of MspI, a methylationinsensitive restriction endonuclease. Studies on isolated nuclei by Hansen et al. (1988) have shown that the methylated human PGK-1 promoter on the $\mathrm{Xi}$ is $>100$ fold less sensitive to $M s p I$ digestion than the same unmethylated region is on the Xa. Antequera et al. (1989) obtained similar results for mouse HPRT. Thus, this line of evidence indicates that the methylated PGK-1 island on the $\mathrm{Xi}$ should bind $\mathrm{MeCP}$, but we observe no protein footprints in vivo. Because $\mathrm{MeCP}$ is not sequence-specific, one possible explanation for this result might have been tight but random binding of MeCP. Present evidence, however, is against random, tight interactions. Tight binding should give a strongly decreased DMS reactivity throughout the methylated CpG island, but this is not seen. MeCP requires $15 \mathrm{CpGs}$ for binding; thus, interactions at each site are likely to be weak. Like histones, MeCP binding may not greatly affect DMS accessibility to guanine $N 7$ in the major groove of the DNA helix.

Our current working hypothesis continues to be that the methylated PGK-1 island on the $\mathrm{Xi}$ is packaged in nucleosomes associated with $\mathrm{MeCP}$, as suggested by Meehan et al. (1989). This packaging would preclude the binding of transcription factors, including Sp1. Studies with agents other than DMS, such as DNases that probe nucleosomal structure, will be required to test this model. Because random binding is rather likely, these studies will need to be quantitative, measuring, for example, band intensities above and below HpaII sites as we were able to do here for DMS studies.

\section{How is the methylation difference between $\mathrm{X} a$ and Xi maintained?}

Our results dramatically illustrate that in human-hamster cell lines, all of the 120 potentially methylatable sites in the CpG island of PGK-1 are maintained without apparent methylation on the $\mathrm{Xa}$. We believe that $10 \%$ methylation would have been detectable at most sites. In a separate study, LMPCR was used to focus on the methylation of certain $\mathrm{HpaII}$ and NarI sites (positions +23 and -343 ) (Steigerwald et al. 1990). In that study, which used restriction-cut fragments to obtain methylation information, the experiment was designed to give a positive signal from a methylated site (longer frag- 
ment), as well as from an unmethylated site (shorter fragment).

These experiments showed no detectable methylation on $\mathrm{Xa}$ and no detectable undermethylation on the $\mathrm{Xi}$, and it was concluded that the methylation differential was $>50$-fold. There has not been selection for PGK-1 activity in the cell lines used for this study, yet two alternate states of the CpG island (fully unmethylated, or fully methylated) have been stably maintained for $>30$ cell generations since the last cell cloning, even in a heterologous hamster-human system. How is this accomplished? High cooperativity is often invoked to explain the low abundance of intermediate states, in this case, the absence of partially methylated islands. Cooperativity may be part of the story, but patchwork methylation can be observed on the $\mathrm{Xi}$ in clones derived from azacytidine-treated cells (G.P. Pfeifer, S.D. Steigerwald, R.S. Hansen, S.M. Gartler, and A.D. Riggs, unpubl.); thus, cooperativity seems limited. In addition, simple cooperativity seems inadequate for long-term stability such as is seen for $X$ inactivation. The reasons are at least twofold. First, on the Xa, occasional de novo methylation events in a population of cells should cause a drift toward methylation, especially because gene silencing and de novo methylation at HpaII sites at autosomal CpG islands does occur in tissue culture (Renzo et al. 1989; Jones et al. 1990). Second, in a growing population, failure to maintain a methylated site with $100 \%$ efficiency results in dilution and eventual complete loss of the methylated site, unless dilution is counteracted by significant de novo methylation. Rather than relying on perfect maintenance efficiency, a more dynamic system with an error-correction mechanism seems more likely. Whatever the complete mechanism, one component could be that the proteins (large protein complex?) observed on the Xa are crucially involved in keeping this region methylation free by inhibiting both de novo and maintenance activity of DNA methyltransferase, which is a bulky $190-\mathrm{kD}$ protein (Pfeifer and Drahovsky 1986).

\section{Methods}

\section{Cells and cell lines}

Chinese hamster hybrid cells containing either a human Xa (Y162-11C) or Xi (X86T2) (Hansen et al. 1988) were kindly provided by R.S. Hansen and S.M. Gartler (Seattle, WA). HeLa cells were strain S315 obtained from G. Attardi (Pasadena, CA). Human lymphocytes were obtained from heparinized blood of healthy donors by centrifugation on Histopaque (Sigma) gradients.

\section{In vivo footprinting}

In vivo DMS footprinting was performed on cultured cells $\left(5 \times 10^{6}\right.$ to $\left.5 \times 10^{7}\right)$ by replacing the culture medium with medium containing $10 \%$ fetal calf serum and $0.1 \%$ DMS (freshly prepared) and incubating at room temperature for $5 \mathrm{~min}$. Other concentrations of DMS and various incubation times have revealed the same footprints. The DMS-containing medium was quickly removed, and cells were washed with medium without DMS and detached by trypsin treatment. The cell suspension was diluted 10-fold by adding ice-cold phosphate-buffered sa- line (PBS), and cells were collected by centrifugation. Lymphocytes were resuspended in RPMI medium containing $5 \%$ fetal calf serum; DMS was added to a final concentration of $0.1 \%$, and cells were incubated for $10 \mathrm{~min}$ at room temperature. The reaction was quenched by adding a 10-fold volume of ice-cold PBS followed by centrifugation. After washing with ice-cold PBS, nuclei were prepared (Wijnholds et al. 1988), and DNA was purified $[300 \mu \mathrm{g} / \mathrm{ml}$ proteinase $\mathrm{K}, 20 \mathrm{mM}$ Tris- $\mathrm{HCl}(\mathrm{pH} 8), 20$ $\mathrm{mm} \mathrm{NaCl}, 20 \mathrm{~mm}$ EDTA, $1 \%$ SDS for $3 \mathrm{hr}$ at $\left.37^{\circ} \mathrm{C}\right]$. After phenol/chloroform extraction, the DNA was precipitated in ethanol and redissolved in $10 \mathrm{mM}$ Tris- $\mathrm{HCl}(\mathrm{pH} \mathrm{7.8)}, 1 \mathrm{~mm}$ EDTA. The viscosity of the DNA solution was reduced by digestion with EcoRI, which does not cut within the region to be analyzed. After restriction digestion, DNA was extracted once with phenol/chloroform and ethanol-precipitated. The DNA was dissolved in $1 \mathrm{M}$ piperidine (Sigma), and the strand scission reaction was performed in sealed tubes at $95^{\circ} \mathrm{C}$ for $30 \mathrm{~min}$. The fragments were precipitated in $0.3 \mathrm{M}$ sodium acetate with 2.5 volumes of ethanol at $-70^{\circ} \mathrm{C}$. After centrifugation, pellets were washed twice in $80 \%$ ethanol. Residual traces of piperidine were removed by drying the sample overnight in a Speedvac concentrator. At this stage, it is usually useful to analyze the DNA on an agarose gel. For optimum molecule usage, the average fragment size length should be $<500$ nucletoides. If this is not the case, the in vivo DMS treatment has been relatively inefficient, and more DNA has to be used as starting material in the Sequenase reaction (see below). To obtain similar band intensities in individual lanes of the sequencing gel, approximately equal amounts of DNA $11-3 \mu \mathrm{g}$ as estimated from the gel) were processed for the Sequenase reaction, as described below. Reducing this amount of DNA may result in occasional missing of certain bands, and this could be mistaken as a footprint (Mueller and Wold 1989; Pfeifer et al. 1989).

\section{Base-specific DNA cleavage}

Between 10 and $50 \mu \mathrm{g}$ DNA, prepared as above, was used per base-specific reaction. This amount is sufficient for analysis with at least 10 different primer sets. For analysis of cytosine methylation, DNA was cleaved with hydrazine in the presence of $1.5 \mathrm{M} \mathrm{NaCl}$ (Maxam and Gilbert 1980). Hydrazine cleavage of $30 \mu \mathrm{g}$ genomic DNA for $20 \mathrm{~min}$ at $20^{\circ} \mathrm{C}$ resulted in an average fragment size of 100-200 nucleotides. DNA was piperidinecleaved and precipitated as described above for in vivo footprinting. For the methylation studies, cloned DNA was used as an unmethylated control. Plasmid pSPT19.1, which contains the PGK-1 5' region (Singer-Sam et al. 1984), was linearized with EcoRI and diluted to the single-copy level, with Micrococcus luteus DNA as a carrier. G, G + A, T + C, and C reactions were performed on HeLa DNA, and these were included on the sequencing and footprinting gels to provide position markers.

\section{$L M P C R$}

Gene-specific oligonucleotide primers were annealed to the piperidine-cleaved DNA fragments and extended to blunt ends by using Sequenase as described (Pfeifer et al. 1989). A complete protocol for LMPCR-aided genomic sequencing is available upon request. The following oligonucleotide primer sets (see Fig. 1) were used for the Sequenase reaction (primers 1) and PCR amplification (primers 2): For sequencing the lower strand, we used primer set A (primer A1, 5'-AAGTCGGGAAGGTTCCTT, primer A2, 5'-AAGGTTCCTTGCGGTTCGCGGCG, nucleotides -238 to -208 ), primer set C (primer C1, 5'-ATTCCAGGGGTTGGGGT, primer C2, 5'GGGTTGGGGTTGCGCCTTTTCCAA, nucleotides -436 to -406), primer set E (primer E1, 5'-TGTGGCCAA- 
TAGCGGCT, primer E2，5'-AATAGCGGCTGCTCAGCAGGGCG, nucleotides -112 to -83 ), primer set $G$ (primer G1, 5'-TCACGTCCGTTCGCAGC, primer G2, 5'CCGTTCGCAGCGTCACCCGGATC); for sequencing the upper strand, we used primer set D (primer Dl, 5'TTTGTCACGTCCGGCAC, primer D2, 5'-ACGCCGCGAACCGCAAGGAACCT, nucleotides -192 to -229 , primer set $\mathrm{F}$ (primer F1, 5' -CGTCCAGCTTGTCCAGC, primer F2, 5'-TCCAGCGTCAGCTTGTTAGAAAGCG, nucleotides +134 to +99 ), primer set $\mathrm{H}$ (primer $\mathrm{Hl}, 5^{\prime}$-CCGGAGGCTTGCAGAAT, primer H2, 5'-GCTTGCAGAATGCGGAACACCGCG, nucleotides +25 to -5 ), and primer set $\mathrm{J}$ (primer J1，5'-GCGGTCGGCGCGCTG， primer J2，5'-CATCGCGGTCGGCGCGCTGCCA, nucleotides -120 to -137 ). Ligation of the oligonucleotide linker to the blunt-ended primer-extended molecules was done as described (Mueller and Wold 1989). After precipitation of the DNA, PGK-1-specific fragments were amplified with Taq polymerase by using the longer oligonucleotide of the linker and primers 2 as described (Pfeifer et al. 1989). Seventeen to 18 amplification cycles were performed. After amplification and precipitation of the DNA, the fragments were separated on sequencing gels $150 \times 0.04 \mathrm{~cm}$ for footprinting; $95 \times 0.04 \mathrm{~cm}$ for 5-methylcytosine determination). The sequences were visualized by autoradiography after electroblotting to nylon membranes and hybridization with a single-stranded probe (Pfeifer et al. 1989). These hybridization probes did not overlap with the sequence of the primers used for PCR amplification. Primer sets D and F, and G and E, respectively, were included simultaneously in primer extension and amplification reactions. The sequence ladders for the individual primers were then visualized separately by rehybridization of the nylon membrane (Pfeifer et al. 1989).

\section{Acknowledgments}

The technical assistance of Cheryl Clark is gratefully acknowledged. This work was supported by a National Institute of Aging grant (AG08196) to A.D.R. and a fellowship from the Deutsche Forschungsgemeinschaft (Pf 212/1-1) to G.P.P.).

The publication costs of this article were defrayed in part by payment of page charges. This article must therefore be hereby marked "advertisement" in accordance with 18 USC section 1734 solely to indicate this fact.

\section{References}

Adams, R.L.P. and R.H. Burdon. 1985. Molecular biology of DNA methylation. Springer Verlag, New York.

Adra, C.N., P.H. Boer, and M.W. McBurney. 1987. Cloning and expression of the mouse pgk-1 gene and the nucleotide sequence of its promoter. Gene 60: 65-74.

Antequera, F., D. Macleod, and A.P. Bird. 1989. Specific protection of methylated CpGs in mammalian nuclei. Cell 58: 509-517.

Becker, P.B., S. Ruppert, and G. Schütz. 1987. Genomic footprinting reveals cell-type specific DNA binding of ubiquitous factors. Cell 51: 435-445.

Ben-Hattar, J., P. Beard, and J. Jiricny. 1989. Cytosine methylation in CTF and Spl recognition sites of an HSV tk promoter: Effects on transcription in vivo and on factor binding in vitro. Nucleic Acids Res. 17: 10179-10190.

Bird, A.P. 1986. CpG-rich islands and the function of DNA methylation. Nature 321: 209-213.

1987. CpG islands as gene markers in the vertebrate nucleus. Trends Genet. 3: 342-347.

Bolden, A.H., C.M. Nalin, C.H. Ward, M.S. Poonian, and A. Weissbach. 1986. Primary DNA sequence determines sites of maintenance and de novo methylation by mammalian DNA methyltransferase. Mol. Cell. Biol. 6: 1135-1140.

Briggs, M.R., J.T. Kadonaga, S.P. Bell, and R. Tjian. 1986. Purification and biochemical characterization of the promoterspecific transcription factor Sp1. Science 234: 47-52.

Carotti, D., F. Palitti, P. Lavia, and R. Strom. 1989. In vitro methylation of CpG-rich islands. Nucleic Acids Res. 17: 9219-9229.

Cedar, H. 1988. DNA methylation and gene activity. Cell 53: 3-4.

Church, G.M. and W. Gilbert. 1984. Genomic sequencing. Proc. Natl. Acad. Sci. 81: 1991-1995.

Comings, D.E., D.C. Harris, T.A. Okada, and G. Holmquist. 1977. Nuclear proteins. IV. Deficiency of non-histone proteins in condensed chromatin of Drosophila virilis and mouse. Exp. Cell Res. 105: 349-365.

Cooper, D.N., M.H. Taggart, and A.P. Bird. 1983. Unmethylated domains in vertebrate DNA. Nucleic Acids Res. 11: 647-658.

Crowther, P.J., A.L. Cartwright, A. Hockings, S. Jefferson, M.D. Ford, and D.M. Woodcock. 1989. The effect of E. coli host strain on the consensus sequence of regions of the human L1 transposon. Nucleic Acids Res. 17: 7229-7239.

Doerfler, W. 1983. DNA methylation and gene activity. Annu. Rev. Biochem. 52: 92-124.

Ephrussi, A., G.M. Church, S. Tonegawa, and W. Gilbert. 1985. B lineage specific interactions of an immunoglobulin enhancer with cellular factors in vivo. Science 227: 134-140.

Gartler, S.M. and A.D. Riggs. 1983. Mammalian X-chromosome inactivation. Annu. Rev. Genet. 17: 155-190.

Grant, S.G. and V.M. Chapman. 1988. Mechanisms of X chromosome regulation. Annu. Rev. Genet. 22: 199-233.

Grünwald, S. and G.P. Pfeifer. 1989. Enzymatic DNA methylation. Prog. Clin. Biochem. Med. 9: 61-103.

Hansen, R.S., N.A. Ellis, and S.M. Gartler. 1988. Demethylation of specific sites in the $5^{\prime}$ region of the inactive $\mathrm{X}$-linked human phosphoglycerate kinase gene correlates with the appearance of nuclease sensitivity and gene expression. Mol. Cell. Biol. 8: 4692-4699.

Harrington, M.A., P.A. Jones, M. Imagawa, and M. Karin. 1988. Cytosine methylation does not affect binding of transcription factor Spl. Proc. Natl. Acad. Sci. 85: 2066-2070.

Hermann, R., A. Hoeveler, and W. Doerfler. 1989. Sequencespecific methylation in a downstream region of the late E2A promoter of adenovirus type 2 DNA prevents protein binding. J. Mol. Biol. 210: 411-415.

Höller, M., G. Westin, J. Jiricny, and W. Schaffner. 1988. Sp1 transcription factor binds DNA and activates transcription even when the binding site is CpG methylated. Genes Dev. 2: $1127-1135$.

Huang, L.H., R. Wang, M.A. Gama-Sosa, S. Shenoy, and M. Ehrlich. 1984. A protein from human placental nuclei binds preferentially to 5-methylcytosine-rich DNA. Nature 308: 293-295.

Iguchi-Ariga, S.M.M. and W. Schaffner. 1989. CpG methylation of the cAMP-responsive enhancer/promoter sequence TGACGTCA abolishes specific factor binding as well as transcriptional activation. Genes Dev. 3: 612-619.

James, T.C. and S.C. Elgin. 1986. Identification of a nonhistone chromosomal protein associated with heterochromatin in Drosophila melanogaster and its gene. Mol. Cell. Biol. 6: $3862-3872$.

Jones, P.A., M.J. Wolkowicz, M.A. Harrington, and F. Gonzales. 1990. Methylation and expression of the MyoDl determination gene. Philos. Trans. R. Soc. Lond. B 326: 277-284.

Kaslow, D.C. and B.R. Migeon. 1987. DNA methylation stabi- 
lizes $\mathrm{X}$ chromosome inactivation in eutherians but not in marsupials: Evidence for multistep maintenance of mammalian X dosage compensation. Proc. Natl. Acad. Sci. 84: 6210-6214.

Keith, D.H., J. Singer-Sam, and A.D. Riggs. 1986. Active X chromosome DNA is unmethylated at eight CCGG sites clustered in a guanosine-plus-cytosine-rich island at the $5^{\prime}$ end of the gene for phosphoglycerate kinase. Mol. Cell. Biol. 6: $4122-4125$.

Kovesdi, I., R. Reichel, and J.R. Nevins. 1987. Role of an adenovirus E2 promoter binding factor in E1A-mediated coordinate gene control. Proc. Natl. Acad. Sci. 84: 2180-2184.

Lee, K.A.W., J.S. Fink, R. Goodman, and M. Green. 1989. Distinguishable promoter elements are involved in transcriptional activation by Ela and cyclic AMP. Mol. Cell. Biol. 9: 4390-4397.

Levinger, L. and A. Varshavsky. 1982. Protein D1 preferentially binds A + T-rich DNA in vitro and is a component of Drosophila melanogaster nucleosomes containing $\mathrm{A}+\mathrm{T}$-rich satellite DNA. Proc. Natl. Acad. Sci. 79: 7152-7156.

Lin, D. and A.C. Chinault. 1988. Comparative study of DNase I sensitivity at the X-linked human HPRT locus. Somatic Cell Mol. Genet. 14: 261-272.

Lyon, M.F. 1988. The William Allan Memorial Award address: $\mathrm{X}$-chromosome inactivation and the location and expression of X-linked genes. Am. J. Hum. Genet. 42: 8-16.

Maxam, A.M. and W. Gilbert. 1980. Sequencing end-labeled DNA with base-specific chemical cleavages. Methods Enzymol. 65: 499-560.

McGhee, J.D. and G. Felsenfeld. 1979. Reaction of nucleosome DNA with dimethyl sulfate. Proc. Natl. Acad. Sci. 76: $2133-2137$.

Means, A.L. and P.J. Farnham. 1990. Transcription initiation from the dihydrofolate reductase promoter is positioned by HIP1 binding at the initiation site. Mol. Cell. Biol. 10: 653661.

Meehan, R.R., J.D. Lewis, S. McKay, E.L. Kleiner, and A.P. Bird. 1989. Identification of a mammalian protein that binds specifically to DNA containing methylated CpGs. Cell 58: 499-507.

Migeon, B.R., S.J. de Beur, and J. Axelman. 1989. Frequent derepression of G6PD and HPRT on the marsupial inactive $X$ chromosome associated with cell proliferation in vitro. Exp. Cell Res. 182: 597-609.

Monk, M. 1986. Methylation and the X chromosome. BioEssays 4: 204-208.

Mueller, P.R. and B. Wold. 1989. In vivo footprinting of a muscle specific enhancer by ligation mediated PCR. Science 246: $780-786$.

Nilsson, P., B. Hallberg, A. Thornell, and T. Grundström. 1989. Mutant analysis of protein interactions with nuclear factor I binding site in the SL3-3 virus enhancer. Nucleic Acids Res. 17: 4061-4075.

Pfeifer, G.P. and D. Drahovsky. 1986. DNA methyltransferase polypeptides in mouse and human cells. Biochim. Biophys. Acta 868: 238-242.

Pfeifer, G.P., S.D. Steigerwald, P.R. Mueller, B. Wold, and A.D. Riggs. 1989. Genomic sequencing and methylation analysis by ligation mediated PCR. Science 246: 810-813.

Razin, A. and A.D. Riggs. 1980. DNA methylation and gene function. Science 210: 604-610.

Renzo, A., L. Bouchard, C.J. Mongeau, and M. Bastin. 1989. Effect of CpG-rich sequences in transformation and tumorigenesis by polyomavirus. Oncogene 4: 1469-1475.

Reuter, G., M. Giarre, J. Farah, J. Gausz, A. Spierer, and P. Spierer. 1990. Dependence of position-effect variegation in
Drosophila on dose of a gene encoding an unusual zincfinger protein. Nature 344: 219-223.

Riggs, A.D. 1989. DNA methylation and cell memory. Cell. Biophys. 15: 1-13.

. 1990. DNA methylation and late replication probably aid cell memory, and type I DNA reeling could aid chromosome folding and enhancer function. Philos. Trans. R. Soc. Lond. B 326: 285-297.

Riggs, A.D. and P.A. Jones. 1983. 5-Methylcytosine, gene regulation and cancer. Adv. Cancer Res. 40: 1-30.

Saluz, H.P. and J.P. Jost. 1987. A laboratory guide to genomic sequencing. Birkhäuser, Boston.

Saluz, H.P., J. Jiricny, and J.P. Jost. 1986. Genomic sequencing reveals a positive correlation between the kinetics of strandspecific DNA demethylation of the overlapping estradiol/ glucocorticoid-receptor binding sites and the rate of avian vitellogenin mRNA synthesis. Proc. Natl. Acad. Sci. 83: 7167-7171.

Singer-Sam, J., D.H. Keith, K. Tani, R.L. Simmer, L. Shively, S. Lindsay, A. Yoshida, and A.D. Riggs. 1984. Sequence of the promoter region of the gene for human X-linked 3-phosphoglycerate kinase. Gene 32: 409-417.

Smith, S.S., D.J. Baker, and L.A. Jardines. 1989. A G4-DNA/BDNA junction at codon 12 of c-Ha-ras is actively and assymetrically methylated by DNA(cytosine-5/methyltransferase. Biochem. Biophys. Res. Commun. 160: 1397-1402.

Steigerwald, S.D., G.P. Pfeifer, and A.D. Riggs. 1990. Ligationmediated PCR improves the sensitivity of methylation analysis by restriction enzymes and detection of specific DNA strand breaks. Nucleic Acids Res. 18: 1435-1439.

Toniolo, D., G. Martini, B.R. Migeon, and R. Dono. 1988. Expression of the G6PD locus on the human X chromosome is associated with demethylation of three $\mathrm{CpG}$ islands within $100 \mathrm{~kb}$ of DNA. EMBO I. 7: 401-406.

Turker, M.S., K. Swisshelm, A.C. Smith, and G.M. Martin. 1989. A partial methylation profile for a CpG site is stably maintained in mammalian tissues and cultured cell lines. $J$. Biol. Chem. 264: 11632-11636.

Wang, R., X.Y. Zhang, R. Khan, Y. Zhou, L.H. Huang, and M. Ehrlich. 1986. Methylated DNA-binding protein from human placenta recognizes specific methylated sites on several prokaryotic DNAs. Nucleic Acids Res. 14: 9843-9859.

Wang, Z. and M.M. Becker. 1988. Selective visualization of gene structure with ultraviolet light. Proc. Nat1. Acad. Sci. 85: 654-658.

Watt, F. and P.L. Molloy. 1988. Cytosine methylation prevents binding to DNA of a HeLa cell transcription factor required for optimal expression of the adenovirus major late promoter. Genes Dev. 2: 1136-1143.

Wijnholds, J., J.N.J. Philipsen, and G. AB. 1988. Tissue-specific and steroid-dependent interaction of transcription factors with the oestrogen-inducible apoVLDLII promoter in vivo. EMBO J. 7: 2757-2763.

Wolf, S.F., D.J. Jolly, K.D. Lunnen, J. Axelman, and B.R. Migeon. 1984. Methylation of the hypoxanthine phosphoribosyltransferase locus on the human inactive $\mathrm{X}$ chromosome: Implications for $\mathrm{X}$ chromosome inactivation. Proc. Natl. Acad. Sci. 81: 2806-2810.

Yang, T.P., J. Singer-Sam, J.C. Flores, and A.D. Riggs. 1988. DNA binding factors for the CpG-rich island containing the promoter of the human X-linked PGK gene. Somatic Cell Mol. Genet. 14: 461-472.

Yen, P.H., P. Patel, A.C. Chinault, T. Mohandas, and L.J. Shapiro. 1984. Differential methylation of hypoxanthine phosphoribosyltransferase genes on active and inactive human $\mathrm{X}$ chromosomes. Proc. Natl. Acad. Sci. 81: 1759-1763. 


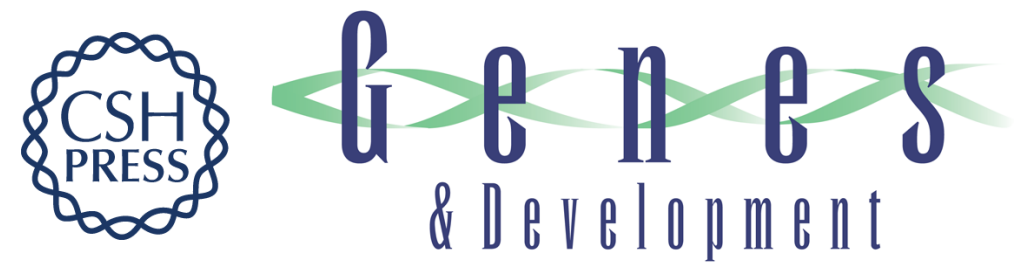

\section{In vivo footprint and methylation analysis by PCR-aided genomic sequencing: comparison of active and inactive $X$ chromosomal DNA at the CpG island and promoter of human PGK-1.}

G P Pfeifer, R L Tanguay, S D Steigerwald, et al.

Genes Dev. 1990, 4:

Access the most recent version at doi:10.1101/gad.4.8.1277

References This article cites 63 articles, 25 of which can be accessed free at:

http://genesdev.cshlp.org/content/4/8/1277.full.html\#ref-list-1

License

Email Alerting Receive free email alerts when new articles cite this article - sign up in the box at the top

Service right corner of the article or click here.

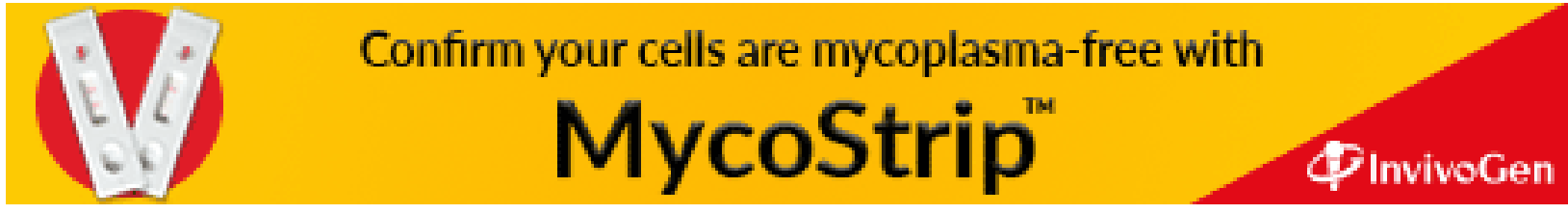

